\title{
PENGEMBANGAN BAHAN AJAR MATA KULIAH MATEMATIKA DISKRIT BERBASIS KONSTRUKTIVISME
}

\author{
Majidah Khairani Siregar ${ }^{*}$, Fepryna Yenti ${ }^{* *}$ \\ Program Studi Pendidikan Matematika,Fakultas Keguruan dan Ilmu Pendidikan \\ STKIP Ahlussunnah Bukittinggi, Sumatera Barat \\ e-mail*. majidah_mns@yahoo.com, ${ }^{* *}$ feprynayenti@gmail.com
}

\begin{abstract}
Abstrak. Tujuan penelitian ini adalah mengembangkan bahan ajar berbasis konstruktivisme yang valid, praktis dan efektif pada mata kuliah matematika diskrit. Bahan ajar yang dikembangkan berupa buku kerja matematika diskrit berbasis konstruktivisme. Penelitian ini termasuk dalam penelitian pengembangan dengan yang terdiri dari 3 tahap yaitu: tahap Pendefenisian, tahap Perancangan dan tahap Pengembangan. Hasil penelitian menunjukkan bahwa (1) bahan ajar dinyatakan valid oleh validator, yang artinya bahan ajar valid dan sudah dapat digunakan oleh mahasiswa yang mengambil matakuliah Matematika Diskrit di STKIP Ahlussunnah. Dan hasil analisis validasi RPKPS termasuk dalam kategori valid, artinya RPKPS yang digunakan sudah sesuai dengan bahan ajar yang digunakan. (2) Analisis hasil angket diperoleh dalam kategori praktis, yang artinya bahan ajar mudah digunakan. 3) Analisis hasil tes menunjukkan bahwa penggunaan bahan ajar belum efektif, walaupun nilai ratarata hasil ujian mahasiswa berada pada kategori baik. Dengan demikian dapat disimpulkan bahwa bahan ajar sudah valid praktis dan efektif.
\end{abstract}

Kata Kunci: Pengembangan, buku kerja, konstruktivisme

Abstract.The purpose of this study is to develop constructivist based teaching materials that are valid, practical and effective in matematika diskrit lesson. Teaching materials developed in the form of matematika diskrit workbooks based on constructivism. This research is included in the development research which consists of 3 stages, They are: Definition stage, Design stage and Development stage. The results showed that (1) the teaching material was declared valid by the validator, which meant the teaching material was valid and could be used by students taking matematika diskrit lesson at STKIP Ahlussunnah. And the results of the RPKPS validation analysis are included in the valid category, it mean that the RPKPS used is appropriated with the teaching material used. (2) Analysis the results of questionnaires is obtained in practical categories, which means that teaching materials are easy to use. 3) The results shows that the use of teaching materials has not been effective, while the average score of student examination results is at a good category. Thus it can be concluded that the teaching material is valid, practically and effective.

Keywords: development; workbook; constructivist

\section{Pendahuluan}

Proses pembelajaran di perguruan tinggi tidak sama dengan proses pembelajaran di sekolah. Sebab, "Mahasiswa pada umumnya telah mempunyai kematangan dalam berpikir dan menentukan pilihan. Dari segi umur pun, mahasiswa telah dianggap matang dibandingkan dengan siswa sekolah menengah" (Hisyam, 2002). Mahasiswa sebagai orang yang sudah dianggap dewasa, hendaknya diperlakukan dengan cara-cara yang sesuai dengan karakteristiknya. Orang dewasa itu biasanya mampu mengarahkan dirinya sendiri, mempunyai pengalaman yang beragam, siap belajar akibat kebutuhan dan lebih menyenangi belajar yang bersifat problem centered.

Matematika Diskrit adalah mata kuliah wajib program studi yang dituangkan dalam kurikulum Pendidikan Matematika STKIP Ahlussunnah Bukittinggi. Matematika Diskrit merupakan mata kuliah yang mempunyai mata kuliah prasyarat. Mata kuliah prasyaratnya 
adalah Analisis Real dan Matematika Dasar. Matematika Diskrit adalah cabang matematika yang mengkaji tentang objek-objek diskrit. Penjabaran materi dalam matakuliah matematika diskrit mempunyai keterkaitan antar topik dan berkelanjutan. Materi yang diberikan akan bisa dipahami jika konsep pendukungnya dipahami dengan jelas. Konsep pendukung materi yang sekarang akan sangat dipengaruhi oleh pemahaman mahasiswa terhadap konsep pendukung materi perkuliahan yang sebelumnya. Dari pengamatan yang peneliti lakukan ketika proses pembelajaran, mahasiswa hanya mendengarkan penjelasan dari dosen meskipun mahasiswa sudah mempunyai buku. Meskipun mahasiswa sudah mempunyai buku, tetapi mahasiswa belum dapat belajar mandiri. Hal ini dikarenakan buku yang dimiliki mahasiswa hanya berisi konsep materi, contoh soal dan latihan. Konsep materi dan contoh soal dipaparkan secara singkat dan kurang komunikatif. Hal ini yang mengakibatkan mahasiswa kurang dapat belajar mandiri pada mata kuliah Matematika Diskrit. Indikasinya dapat dilihat dari nilai mahasiswa yang mengambil matakuliah matematika diskrit semester genap 2016/2017, mahasiswa yang mendapat nilai C mencapai $25 \%$ dan $9 \%$ mendapat nilai D. Walaupun nilai C dalam kategori lulus, tetapi nilai $\mathrm{C}$ dapat mempengaruhi IPK mahasiswa.

Buku paket yang digunakan selama ini adalah buku Matematika Diskrit dengan judul Common TextBook Matematika Diskrit. Pemaparan materi pada Buku paket ini masih sulit dipahami oleh mahasiswa dikarenakan pemaparan materinya kurang komunikatif dan soal yang disajikan begitu banyak tanpa ada kategori penyelesaiannya. Kunci jawaban dari soal tidak ada dicantumkan, sehingga mahasiswa tidak mengetahui kebenaran dari hasil kerjanya. Untuk itu diperlukan suatu alat yang bisa membiasakan mahasiswa untuk belajar secara berkelanjutan dan terarah berupa sebuah buku kerja. Buku kerja merupakan salah satu bahan ajar kompilasi dari buku panduan dan kumpulan soal-soal yang telah dikemas sedemikian rupa yang dibuat secara bertahap untuk melatih dan meningkatkan keterampilan mahasiswa, serta meningkatkan pemahaman tentang tahap-tahap dalam penyelesaian soal.

Salah satu bentuk paham yang sangat membantu dalam meningkatkan pemahaman mahasiswa adalah paham konstruktivis. Menurut paham ini, mahasiswa mengkonstruksi pengetahuan yang sudah ada dengan pengalamannya sendiri sehingga terbentuk pemahaman baru. Hal ini sesuai dengan hasil penelitian (Riyanto \& Siroj, 2011), dalam proses pedekatan konstruktivis siswa sudah mampu mengaktifkan pengetahuan yang dimilikinya dalam rangka mengkonstruk pengetahuan baru melalui proses diskusi. Hal tersebut mengindikasikan bahwa pada proses pembelajaran yang efektif, siswa tidak sekadar menjadi penerima informasi yang pasif melainkan harus mengkonstruksi tentang topik yang dipelajari. Kemampuan siswa dalam mengkonstruksi pengetahuannya diperoleh dari pengetahuan awalnya, sehingga siswa dapat mengkonstruk pembelajaran dalam pengusaan konsep.

Untuk mendukung peningkatan pemahaman mahasiswa maka perlu diadakan bahan ajar. Bahan ajar dapat membuat siswa termotivasi untuk belajar dan hasil belajarnya menjadi lebih bagus, (Pratiwi, 2014). Bahan ajar yang dimaksud merupakan buku kerja dengan berbasiskan pendekatan konstruktivis. Dengan mengerjakan buku kerja diharapkan mahasiswa dapat membentuk pemahaman baru berdasarkan pengetahuan awal dan pengalaman belajarnya sendiri. Setelah mahasiswa paham dengan materi perkuliahan diharapkan mereka menjadi lebih termotivasi dalam belajar. Tujuan penelitian ini menghasilkan bahan ajar yang valid, praktis dan efektif. Buku kerja berbasis konstruktivisme 
dikembangkan berdasarkan karakteristik mahasiswa yang ada di STKIP Ahlussunnah Bukittinggi.

Esensi dari teori konstruktivisme adalah bahwa dalam proses pembelajaran, mahasiswalah yang harus mendapatkan penekanan. Merekalah yang harus aktif mengembangkan pengetahuan mereka, bukan dosen atau orang lain. Mereka yang harus bertanggung jawab terhadap hasil belajarnya. Penekanan belajar mahasiswa secara aktif ini perlu dikembangkan. Kreativitas dan keaktifan mahasiswa akan membantu mereka untuk berdiri sendiri dalam kehidupan kognitif mahasiswa. Seperti hasil yang diperoleh oleh (Supriyono, 2013) dalam penelitiannya bahwa bahan ajar berbasis konstruktivis dapat membuat mahasiswa menjadi kreatif dan aktif. Kreatif maksudnya mahasiswa dapat menghubungkan atau mencari kegunaan materi yang dipelajari dengan kehidupan sehari-hari.

Bahan ajar yang akan dibuat adalah bahan ajar dalam bentuk buku kerja. Banyak penelitian tentang manfaat bahan ajar, salah satunya adalah (Lathiifah, 2011) menyimpulkan bahwa bahan ajar mempunyai efek potensial terhadap kemampuan siswa dalam memecahkan masalah dilihat dari sikap, pengetahuan dan keterampilan serta hasil tes evaluasi akhir siswa. Buku kerja disusun berdasarkan silabus di STKIP Ahlussunnah Bukittinggi. Soal-soal pada buku kerja tersebut dibuat dengan berpedoman kepada buku pegangan dosen, yaitu buku Matematika Diskrit karangan Heri Susanto dan buku Matematika Diskrit karangan I Ketut Budayasa. Buku kerja disusun dengan menggunakan pendekatan konstruktivisme. Dengan alasan buku kerja ini berisi ringkasan materi yang dapat dijadikan sebagai pengetahuan awal bagi mahasiswa. Dengan soal-soal latihan yang diberikan menuntut mahasiswa bekerja dan mengalami sendiri pengetahuan tersebut. Sehingga, mahasiswa memahami materi perkuliahan yang diberikan dan memperoleh pengetahuan baru.

\section{Metode Penelitian}

Penelitian ini merupakan penelitian yang menggunakan metode pengembangan. Karena dalam penelitian ini menghasilkan produk berupa bahan ajar buku kerja Matematika Diskrit. Menurut (Setyosari, 2013)metode pengembangan adalah metode penelitian yang bertujuan untuk menghasilkan sebuah produk dan menguju efisiensinya. Model pengembangan yang digunakan adalah model pengembangan 4D. Model 4-D ini memiliki beberapa tahapan yaitu tahap Define (pendefenisian), tahap Design (perancangan), tahap Development (pengembangan), dan tahap Disseminate (penyebaran). Tahap Disseminate ini tidak dilakukan karena keterbatasan biaya dan waktu dalam penelitian.

Berikut uraian prosedur penelitian yang akan dilakukan:

1. Tahap Analisis Muka-Belakang (Pendefinisian)

Tahap analisis muka-belakang dilakukan untuk mendapatkan gambaran kondisi di lapangan. Tahap ini bisa disebut sebagai tahap analisis kebutuhan (needs assessment). Observasi dilakukan untuk mengetahui seberapa besar dibutuhkannya bahan ajar ini. Analisis yang dilakukan adalah analisis kebutuhan mahasiswa dan analisis konsep matematika diskrit.

2. Tahap Perancangan 
Hasil dari analisis muka-belakang digunakan untuk merancang buku kerja berbasis konstruktivisme di Matematika Diskrit. Buku kerja berbasis konstruktivisme terdiri atas 5 macam, yaitu: buku kerja 1 Induksi matematika, buku kerja 2 Kombinatorik dan peluang diskrit, buku kerja 3 Fungsi pembangkit, buku kerja 4 Relasi rekursif dan buku kerja 5 Grafh. Hal ini dilakukan karena materi Matematika Diskrit terdiri dari 5 pokok bahasan. Untuk memudahkan memahami setiap pokok bahasan, masing-masing diberikan buku kerja.

Masing-masing sub bab pada buku kerja dibuat untuk 1 kali pertemuan. Masing-masing sub bab buku kerja berbasis konstruktivisme berisi materi pokok, materi prasyarat, indikator kompetensi, ringkasan materi, tugas, latihan terbimbing, latihan beserta kunci jawaban dan kesimpulan.

3. Tahap Pengembangan

Setelah buku kerja selesai dirancang kemudian dilakukan tahap validasi dan praktikalitas. Berikut uraian masing-masing tahap.

a. Validasi Ahli

Validasi dilakukan oleh dosen matematika Diskrit di STAIN Batusangkar. Lembar validasi digunakan untuk mengetahui apakah buku kerja dan instrumen yang telah dirancang valid atau tidak. Hasil validasi dari validator terhadap seluruh aspek yang dinilai, disajikan dalam bentuk tabel. Selanjutnya dicari rerata skor tersebut dengan menggunakan rumus:

$$
\begin{aligned}
& R=\frac{\sum_{i=1}^{n} V_{i}}{n}, \text { (Muliyardi, 2006) } \\
& \text { Keterangan: } \\
& \mathrm{R}=\text { rerata hasil penilaian dari para validator } \\
& \mathrm{V}_{\mathrm{i}}=\text { skor hasil penilaian validator ke- } \mathrm{i} \\
& \mathrm{n}=\text { banyak validator }
\end{aligned}
$$

Setelah itu dihitung rerata semua aspek untuk validasi buku kerja berbasis konstruktivisme. Untuk menentukan tingkat kevalidan buku kerja digunakan kriteria berikut:

1) Bila rerata $>3,20$ maka buku kerja dikategorikan sangat valid.

2) Bila $2,40<$ rerata $\leq 3,20$ maka dikategorikan valid.

3) Bila $1,60<$ rerata $\leq 2,40$ maka dikategorikan cukup valid.

4) Bila $0,80<$ rerata $\leq 1,60$ maka dikategorikan kurang valid.

5) Bila rerata $\leq 0,80$ maka dikategorikan tidak valid

b. Praktikalitas oleh mahasiswa

Setelah buku kerja dinyatakan valid selanjutnya dilakukan ujicoba praktikalitas untuk memperoleh informasi tentang kepraktisan atau kemudahan dalam penggunaan buku kerja matematika diskrit berbasis konstruktivisme. Skala penilaian untuk angket menggunakan skala Likert. Untuk mengetahui praktikalitas buku kerja matematika diskrit dianalisis dengan menggunakan rumus persentase.Berdasarkan hasil persentase, respon siswa untuk setiap aspek dikategorikan pada: 
Tabel 1. Kriteria Kepraktisan Respon Mahasiswa

\begin{tabular}{cl}
\hline Persentase (\%) & \multicolumn{1}{c}{ Kriteria kepraktisan } \\
\hline $0-20$ & Tidak praktis \\
$21-40$ & Kurang praktis \\
$41-60$ & Cukup praktis \\
$61-80$ & praktis \\
$81-100$ & Sangat praktis \\
\hline
\end{tabular}

Sumber: (Riduwan, 2005)

c. Efektifitas buku kerja matematika diskrit berbasis konstruktivisme

Tes diberikan kepada subjek uji coba untuk mengetahui keefektifan dalam menggunakan buku kerja matematika diskrit. Tes diberikan kepada siswa bertujuan untuk menganalisis ketercapain tujuan tertentu (Hendriana \& Utari, 2014). Tes yang diberikan adalah tes dalam bentuk esai. Data hasil belajar diperoleh dengan cara menghitung skor mahasiswa yang menjawab masing-masing item sebagaimana terdapat pada lembar tes. Data tersebut dianalisis secara deskriptif, dan jika nilai mahasiswa $75 \%$ mendapatkan nilai dalam kategori baik, berarti bahan ajar buku kerja Matematika Diskrit sudah efektif digunakan dikalangan mahasiswa STKIP Ahlussunah Bukittinggi. Berikut perhitungan kategori nilai yang diperoleh mahasiswa:

Tabel 2. Kriteria Predikat Nilai

\begin{tabular}{ccc}
\hline Nilai & Predikat & Kategori \\
\hline $86-100$ & A & Sangat Baik \\
$81-85$ & A- & Sangat Baik \\
$76-80$ & B+ & Baik \\
$71-75$ & B & Baik \\
$66-70$ & B- & Baik \\
$61-65$ & C & Cukup baik \\
$56-60$ & C & Cukup baik \\
$51-55$ & C- & Cukup baik \\
$46-50$ & D+ & Kurang baik \\
$0-45$ & D & Kurang baik \\
\hline
\end{tabular}

\section{Hasil Penelitian dan Pembahasan}

1. Tahap Analisis Muka-Belakang (Pendefinisian)

Pada tahap pendefinisian dilakukan untuk mengetahui taraf kognitif mahasiswa dan kebutuhan mahasiswa terhadap bahan ajar matakuliah Matematika Diskrit. 
a. Melakukan wawancara Mahasiswa

Wawancara kepada mahasiswa untuk mengetahui kebutuhan mahasiswa tentang bahan ajar matematika diskrit. Hasil yang diperoleh bahwa pendapat mahasiswa yang sudah mengambil mata kuliah matematika diskrit adalah dalam buku referensi yang disarankan oleh Dosen pengampu belum mencukupi dalam satu rujukan, dan penyelesaikan soalsoalnya tidak mempunyai kunci jawaban, hal ini mengakibatkan mahasiswa kesulitan untuk belajar secara mandiri ataupun berkelompok. Oleh karena itu mahasiswa hanya menunggu penjelasan dari Dosen pengampu. Selain itu, dalam memperlajari matematika diskrit terlalu banyak rumus dan teorema sehingga sulit untuk dipahami.

b. Menganalisis silabus mata kuliah Matematika Diskrit

Hal ini bertujuan untuk mengetahui apakah materi yang diajarkan sudah sesuai dengan standar kompetensi dan kompetensi dasar mata kuliah. Selain itu, juga melihat kegiatan perkuliahan yang telah direncanakan. Materi matematika diskrit merupakan matakuliah wajib yang terdiri dari lima bab.

c. Menganalisis buku teks Matematika Diskrit

Berdasarkan hasil analisa buku teks Matematika Diskrit diperoleh bahwa materi dalam matematika diskrit sifatnya berkelanjutan, artinya materi selanjutnya berhubungan dengan materi sebelumnya. Cara penyajian materinya belum dapat mengkonstruksi pengetahuan mahasiswa sehingga mahasiswa kurang dapat belajar secara mandiri. Soal-soal yang disajikan dalam buku teks tidak ada kunci jawabannya sehingga mahasiswa kurang termotivasi untuk menyelesaikan soal-soalnya.

2. Tahap Perancangan

Produk yang diharapkan dari penelitian ini adalah buku kerja berbasis konstruktivisme untuk mata kuliah Matematika Diskrit. Karakteristik dari buku kerja berbasis konstruktivisme adalah sebagai berikut:

a. Pada setiap buku kerja diberikan materi prasyarat yang harus dikuasai mahasiswa sebelum memahami ringkasan materi dan mengerjakan soal.

b. Tujuan perkuliahan dinyatakan dalam bentuk indikator kompetensi. Indikator kompetensi ini dijabarkan berdasarkan kompetensi dasar yang ada pada silabus mata kuliah.

c. Ringkasan materi pada buku kerja berisi inti dari materi perkuliahan yang diadaptasi dari buku Matematika Diskrit karangan Heri Susanto dan buku Matematika Diskrit karangan I Ketut Budayasa. Ringkasan materi dapat dijadikan sebagai pengetahuan awal bagi mahasiswa, di samping penjelasan dosen sewaktu kuliah teori.

d. Tugas berisi soal pendalaman materi. Tugas dapat mendorong kreatifitas berpikir mahasiswa.

e. Latihan terbimbing berisi soal-soal yang telah disusun dari tingkat kesukaran rendah,sedang sampai tinggi. Setiap soal diberikan langkah penyelesaian yang tidak lengkap. Dengan mengisi latihan terbimbing diharapkan mahasiswa memperoleh pengalaman belajar sendiri.

f. Latihan beserta kunci jawabannya berisi soal-soal lanjutan yang memiliki tingkat kesukaran lebih tinggi daripada latihan terbimbing. Pada latihan ini, mahasiswa dapat mengembangkan sendiri jawabannya berdasarkan pemahaman baru yang terbentuk ketika mengisi latihan terbimbing. 
g. Kesimpulan merupakan hasil konstruksi mahasiswa terhadap materi perkuliahan yang telah dipelajari. Mahasiswa diminta membuat kesimpulan dengan bahasa sendiri.

Berikut adalah salah satu bagian dari buku kerja matematika diskrit berbasis konstruktivisme

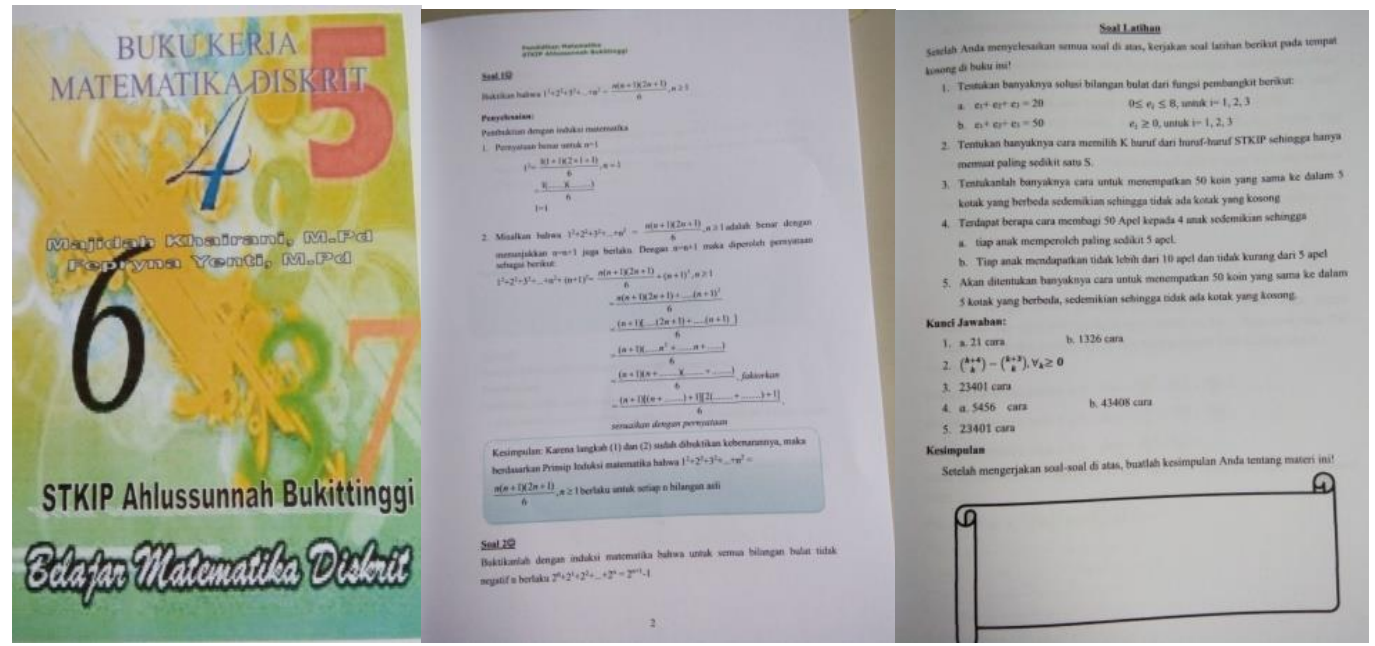

Gambar 1. (1) Cover buku kerja, (2) proses konstruktivisme, (3) Soal dan Kunci jawaban

\section{Tahap Pengembangan}

Buku kerja yang sudah dirancang dikonsultasikan dan didiskusikan dengan pakar Matematika Diskrit dan pendidikan matematika. Validator dalam menvalidasi bahan ajar ini berjumlah 2 orang yaitu dosen Pendidikan Matematika di Batusangkar Ibu Christina Khaidir, M.Pd dan Ibu Yusri Wahyuni, M.Pd. Kegiatan validasi dilakukan dalam bentuk mengisi lembar validasi buku kerja dan diskusi sampai diperoleh buku kerja yang valid dan layak untuk digunakan.

a. Validasi Buku kerja berbasis konstruktivisme

Validasi ini bertujuan untuk mengetahui kebenaran isi materi dan kesesuain buku kerja yang dibuat dengan pendekatan konstruktivime. Hasil validasi bahan ajar dapat dilihat dari Tabel 3 berikut.

Tabel 3. Validasi Buku Kerja Berbasis Konstruktivisme

\begin{tabular}{llcccc} 
No & \multicolumn{1}{c}{ Aspek } & \multicolumn{2}{c}{$\begin{array}{c}\text { Rata-rata Penilaian } \\
\text { Validator }\end{array}$} & Rata-rata & Keterangan \\
\cline { 3 - 6 } & & I & II & & \\
\cline { 3 - 6 } 1 & Tujuan & 3,33 & 2,66 & 2,99 & Valid \\
2 & Rasional & 3,00 & 3,00 & 3,00 & Valid \\
3 & Isi Buku & 3,00 & 2,25 & 2,62 & Valid \\
4 & Karakteristik & 3,14 & 2,86 & 3,00 & Valid \\
5 & Kesesuaian & 3,50 & 3,50 & 3,32 & Valid \\
6 & Bahasa & 2,50 & 2,50 & 2,50 & Valid \\
7 & Bentuk fisik & 2,50 & 2,50 & 2,50 & Valid
\end{tabular}




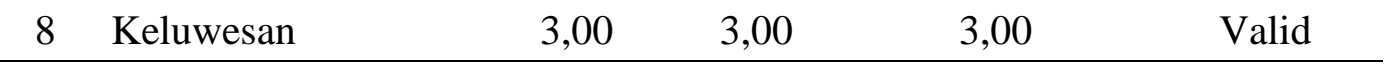

Berdasarkan Tabel 3 dapat dilihat bahwa hasil uji validitas buku kerja matematika diskrit sudah valid dengan rentang 2,50-3,25. Secara keseluruhan buku kerja direvisi sesuai dengan saran validator. Aspek yang paling banyak direvisi adalah bahasa dan bentuk fisik buku ajar. Bahasa yang digunakan belum komunikatif dan bentuk fisiknya masih kurang menarik. Rata-rata validasi untuk keseluruhannya adalah 2,86, dengan demikian bahan ajar sudah layak untuk digunakan.

b. Rencana Program dan Kegiatan Pemelajaran Semester (RPKPS)

Validasi ini bertujuan untuk mengetahui kesesuain isi materi buku kerja yang dibuat dengan RPKPS yang akan dilaksanakan.Validasi dilihat dari segi Format Rencana Pelaksanaan Perkuliahan, Isi Rencana Pelaksanaan Perkuliahan, dan segi tata bahasanya. Rata-rata hasil validasinya adalah 72,22\%. Hal ini menenjukkan bahwa buku kerja yang dirancang sudah sesuai dengan RPKPS yang akan digunakan.

c. Praktikalitas

Pada tahap ini dilakukan ujicoba terbatas di STKIP Ahlussunnah Bukittinggi yaitu mahasiswa yang mengambil matakuliah Matematika Diskrit pada semester ganjil 2017/2018. Ujicoba dilakukan untuk melihat praktikalitas atau keterpakaian buku kerja yang sudah dirancang. Adapun komponen yang diteliti dapat dilihat pada Tabel 4.

Tabel 4. Praktikalitas Buku Kerja Berbasis Konstruktivisme

\begin{tabular}{clcc}
\hline No & Aspek & Rata-rata Nilai Angket & Keterangan \\
\hline 1 & Pelaksanaan Perkuliahan dengan & $67,5 \%$ & Praktis \\
& buku kerja & & \\
2 & Petunjuk Pengisisan buku kerja & $75,7 \%$ & Praktis \\
3 & Isi buku kerja & $78,7 \%$ & Praktis \\
4 & Waktu untuk mempelajari buku & $75,3 \%$ & Praktis \\
& kerja & & \\
\hline
\end{tabular}

Berdasarkan Tabel 4 di atas, dapat dilihat rata-rata praktikalitas adalah 74,3\%. Hal ini menunjukkan bahwa bahan ajar yang dibuat sudah mudah untuk digunakan oleh mahasiswa. Melalui pembelajaran dengan bahan ajar, secara tidak langsung mahasiswa dapat saling berbagi pengetahuan karena mereka saling berinteraksi dalam mempelajari materi matematika diskrit. Rata-rata respon mahasiswa yang paling rendah adalah pada pelaksanaan perkuliahan dengan buku kerja berbasis matematika diskrit, hal ini dapat diartikan kemudahan dalam pelaksanannya sudah dapat dikatakan mudah walaupun dari keempat aspek,aspek inilah yang paling rendah.

Dari hasil observasi dan wawancara dapat disimpulkan bahwa buku kerja Matematika Diskrit mudah digunakan dan memotivasi mahasiswa untuk mempelajarinya. Hal ini dapat dilihat dari proses pembelajaran, pada saat mahasiswa dimintak untuk mengerjakan soal di depan kelas banyak mahasiswa yang ingin mengerjakannya, hal ini dikarenakan dalam buku kerja soal-soal yang diberikan sudah ada kunci jawabannya, sehingga mahasiswa percaya diri untuk menyelesaikannya. Dalam mempelajari matematika diskrit mahasiswa dapat terbantu dengan adalanya 
materi dan contoh soal yang menuntun mahasiswa untuk menyelesaikannya. Hal ini cukup membantu bagi mahasiswa untuk mengkonstruyksi pengetahunnya dalam menyelesaikan atau mempelajari konsep-konsep dalam mata kuliah matematika diskrit. Buku kerja Matematika Diskrit berbasis konstruktivisme dapat membantu mahasiswa untuk menemukan konsep matematika diskrit secara mandiri. Hai ini sesuai dengan hasil penelitian (Fitri, 2017) yang menemukan bahwa pembelajaran menggunakan pendekatan konstruktivisme peserta didik memiliki kemampuan dalam menemukan, memahami, dan menggunakan informasi atau pengetahuan yang dipelajari.

d. Efektivitas

Berdasarkan hasil ujian Matematika Diskrit semester Ganjil 2017/2018 data menunjukkan bahwa nilai rata-ratanya adalah 69 (dalam kategori baik). Nilai yang paling rendah adalah 26 dan yang paling tinggi adalah 100 dengan standar deviasi 21,2. Dari analissi data dapat diperoleh bahwa distribusi nilai mahasiswa tidak begitu jauh dari nilai rata-ratanya. Dari 40 orang mahasiswa yang mengikuti proses pembelajaran dengan menggunakan bahan ajar diperoleh 29 orang yang mendapatkan nilai lebih dari 61. Hal ini berarti 72,5\% mahasiswa mencapai kategori baik dan sangat baik. Karena nilai mahasiswa dalam kategori baik belum mencapai $75 \%$, maka buku kerja matematika diskrit ini belum efektif untuk meningkatkan hasil belajar mahasiswa, walaupun ada peningkatan persentase kategori nilai mahasiswa dari tahun sekarang dengan tahun sebelumnya. Hal ini juga sesuai dengan hasil penelitian (Safitri, 2015) bahwa hasil belajar siswa kelas IX SMK dengan menggunakan bahan ajar berbasis Elearning dan berdasarkan teori konstruktivisme diperoleh perbedaan yang signifikan antara pretest dan posttest.

\section{Kesimpulan dan Saran}

Berdasarkan pembahan dan hasil diperoleh kesimpulan bahwa (1) Bahan ajar dinyatakan valid oleh validator, yang artinya bahan ajar valid dan sudah dapat digunakan oleh mahasiswa yang mengambil matakuliah Matematika Diskrit di STKIP Ahlussunnah. (2) Analisis hasil angket diperoleh dalam kategori praktis, yang artinya bahan ajar mudah digunakan. (3) Analisis hasil tes menunjukkan bahwa penggunaan bahan ajar belum efektif, walaupun nilai rata-rata hasil ujian mahasiswa berada pada kategori baik.

Penelitian ini belum maksimum dikarenakan tahap pengembangan belum menunjukkan keefektipan buku kerja, diharapkan untuk penelitian selanjutnya buku kerja dirancang dengan memperbanyak soal dan membuat persentase banyaknya soal dengan kategori sulit dan mudah seimbang.

\section{Ucapan Terima Kasih}

Segala puji dan syukur penulis panjatkan kepada Allah Rabb alam semesta atas segala rahmat dan karunia-Nya. Penulis mengucapkan terimakasih banyak kepada semua pihak yang membantu dalam penelitian ini. Salah satunya adalah pihak keluarga dan teman sejawat yang menjadi validator dan juga Kemenristekdikti yang membiayai penelitian ini. Penelitian ini dibiayai oleh Kemenristekdikti pada tahun 2018. 


\section{Daftar Pustaka}

Fitri, R. (2017). Pengembangan Perangkat Pembelajaran Berbasis Pendekatan Konstruktivisme untuk Meningkatkan Kemampuan Pemahaman Konsep pada Materi Persamaan Lingkaran. Jurnal JNPM (Jurnal Nasional Pendidikan Matematika), 1(2), 241-257.

Hanggara, Y., \& Amelia, F. (2018). Pengembangan modul statistik pendidikan berbasis CTL untuk meningkatkan kompetensi mahasiswa universitas riau kepulauan batam. PYTHAGORAS: Jurnal Pendidikan Matematika, 7(2), 1-11. Retrieved from https://www.journal.unrika.ac.id/index.php/jurnalphythagoras/article/view/1261/1054

Hendriana, H., \& Utari, S. (2014). Penilaian Pembelajaran Matematika (Kedua). Bandung: PT Redifa Aditama.

Hisyam, Z. dkk. (2002). Desain Pembelajaran di Perguruan Tinggi. Yogyakarta: Center for Teaching Staff Development (CTSD) IAIN Sunan Kalijaga.

Husna, A., \& Himmi, N. (2018). Pengembangan modul berbasis konstruktivisme pada mata kuliah analisis vektor di unrika. PYTHAGORAS: Jurnal Pendidikan Matematika, 7(2), $12-21$.

Lathiifah, I. J. (2011). Pengembangan Bahan Ajar Materi Aturan Pencacahan Menggunakan Pembelajaran Berbasis Masalah di SMA. Jurnal Didaktik Matematika, 2(2), 72-83.

Muliyardi. (2006). Pengembangan Model Pembelajaran Matematika Menggunakan Komik di Kelas 1 Sekolah Dasar. Universitas Surabaya.

Pratiwi, D. (2014). Pengembangan Bahan Ajar Biologi Berbasis Pendekatan SAVI ( Somatic, Auditory, Visual, Intellectual ) Pada Pokok Bahasan Sistem Pernapasan Kelas XI SMA Dalam Meningkatkan Motivasi dan Hasil Belajar Siswa Development of Teaching Materials of Biology Base. Jurnal Edukasi UNEJ, 1(2), 5-9.

Riduwan. (2005). Belajar Mudah Penelitian untuk Guru, Karyawan dan Peneliti Pemula. Bandung: Alphabeta.

Riyanto, B., \& Siroj, R. A. (2011). Meningkatkan kemampuan penalaran dan prestasi matematika dengan pendekatan konstruktivisme pada siswa sekolah menengah atas. Jurnal Pendidikan Matematika, 5(2), 111-128.

Safitri, N. dkk. (2015). Pengembangan Pembelajaran Berbasis Learning dengan Materi Menganalisis Peluang Usaha Kelas XI SMK. Jurnal Tekno Pedagogi, 5(1), 64-81.

Setyosari, P. (2013). Metode Penelitian Pendidikan \& Pengembangan (Keempat). Jakarta: Kencana Prenada Media Group.

Supriyono. (2013). Pengembangan Bahan Ajar Berbasis Konstruktivis Pada Mata Kuliah Telaah Kurikulum Fisika II (TKF II) untuk Mahasiswa Kelas Internasional di Jurusan Fisika UNESA. Jurnal Pendidikan Fisika Dan Aplikasinya (JPFA), 3(1), 31-40. 